Branka Bilen-Katić1 ${ }^{\text {, Nikola Radovanović }}{ }^{2}$ ${ }^{1}$ Intellectual Property Office of the Republic of Serbia ${ }^{2}$ Intellectual Property Office of the Republic of Serbia

\title{
The Role of Intellectual Property in Developing a Knowledge-Based Society
}

UDC: $347.77 / .78$

DOI: 10.7595/management.fon.2014.0007

SPIN' 13, Belgrade, 05-06. November 2013.

A long-time dominant position of protective features in the intellectual property (IP) rights has been neutralized by their commercializing possibilities. Patents, trademarks and other forms of IP are increasingly being seen as trading assets rather than protection agents. The economic approach to intellectual property emphasizes the material value of intellectual property, which can be appropriated only if that property is used economically, regardless of its actual legal protection status. National institutions dealing with IP rights need to have a continuous service-oriented approach with developing new and specialized services to facilitate the needs of societies which tend to base their competitiveness on the strength of knowledge they possess. The process of transformation to a knowledge-based economy demands that companies fully understand and take advantage of the IP system, which is where business support institutions can provide assistance. A contribution to the increase in the use of the IP system by Serbian companies in recent years can be attributed to the introduction of new services by the Intellectual Property Office of the Republic of Serbia.

Keywords: intellectual property, knowledge society, economy, patents, Serbia.

\section{Intellectual property system in knowledge-based economy}

At the start of the last decade of the 20th century, globalization and technological revolution challenged the principles of world economy. Just like the steam engine and railway transport were triggers for the deepest changes in the sphere of social and economic organization of society at the beginning of the industrial era, the computer and the Internet initiated the transformation of social relations in the direction of the information era (Levi-Jakšić, 1995; Harris et al, 1998). Fast and cheap electronic communication worldwide provides an easy access to information and transforms it into active knowledge, but also enables an efficient performance of business transactions, such as the provision of various services regardless the geographic distances. As a response to these changes, the European Union started investing significant efforts in the development of competitiveness of its economy and supporting innovativeness, education and research. Prerequisites for economic development of a society in the knowledge-based economy include the soundness of intellectual property system and its efficient utilization.

Economically speaking, intellectual property, i.e. intellectual assets, can be considered as goods which at first must be created, i.e., "produced", and then commercialized, i.e., made economically functional for making profit (Grandstand, 1999; Bader, 2006). The economical perspective of intellectual property widens the presented concept to all kinds of intellectual property (thus including more than it is envisaged as a possible subject matter of protection by the intellectual property laws), under the condition that some legal or material mechanism is secured for appropriation of profit for the economic utilization of that property (Cowan and Harrison, 2001). The most striking form of that concept of intellectual property is the know-how, which is categorised as a "soft IP". Exclusivity with regard to the economic utilization of the know-how is obtained by the actual inaccessibility of the know-how to others, and not on the grounds of exclusive rights. Furthermore, information and knowledge which have practical use in economic life can be the subject matter of intellectual property even when they are not the subject matter of the legal protection, or the subject matter of know-how (Sveiby, 1997; Van Caenegem, 2002). One of the examples which describes this is the socalled lead-time, which equals a situation when a company gained the advantageous market position which enabled it to recover the investment in creating that asset in a reasonable time period, and to maintain the 
advantage over the competition in a longer period of time due to the earlier start of using a given intellectual property (Al-Ali, 2003). In a word, the economic approach to intellectual property focuses on the economic value underlying the intellectual property, which can be materialized and appropriated only if that property is used economically, regardless of whether it is legally protected or not.

Having in mind the abovementioned, it can be stated that the intellectual property rights have several basic functions. The first function is to stimulate the "production" of creations by providing a possibility of gaining legal monopoly on the economic exploitation of new intellectual creations, such as inventions, plant varieties, topographies of integrated circuits and copyrights. In such a way, contribution is given to the technical and cultural progress of a society. The second function is to reduce the information gap between the subjects which provide and the subjects which demand certain goods and services on the market, by securing an exclusive right for the utilization of distinctive signs (trademarks, geographical indications of origin and industrial designs), which reduces transaction costs, stimulates investments into the quality of goods and services and contributes to the efficiency of the market. The third function is in the facilitation of the transaction of rights for the use of intellectual property assets. The fourth function is the logical outcome of the previous one: intellectual property rights facilitate economic implementation of the protected intellectual property assets. However, in the cases when the right holder has no capacity or interest to directly utilize a certain intellectual property asset, he or she can assign or license that right to the subject which has the capacity and the interest for doing it. In such a way, due to the legal protection of a non-material asset, an intellectual property asset finds its way to practical implementation.

In the countries in transition, such as the Republic of Serbia, the intellectual property right has one additional function, which, from the point of view of current economic policy, sometimes comes as a priority. It is a function of attracting foreign direct investments (Kanwar \& Evenson, 2009). In the conditions of global economy, capital searches for favourable conditions for doing business. Efficient legal protection of intellectual property encourages foreign companies to import products and services based on new technologies, renowned trademarks and service marks, and the so-called creative industry into the country that facilitates these conditions. On the other hand, an efficient system of intellectual property protection represents a constituent part of the business environment which favourably influences the development of host knowledgebased economy, stimulates research and development projects and the development of the sector of new economy (Kanwar \& Evenson, 2009; Yang \& Maskus, 2009; Bilen-Katić, 2010). In such a way, Serbian economy can transform from a predominantly net-user into a net-provider of intellectual property. Observed in the middle and long-terms, it can favourably influence the results in foreign trade.

\section{Intellectual property rights in the Republic of Serbia}

The Republic of Serbia is a country with a long tradition in the legal protection of intellectual property. The Kingdom of Serbia was one of the 11 founding states of the Paris Union for the protection of intellectual property in 1883. Although the first Office for the protection of industrial Property in the Kingdom of Serbs, Croats and Slovenians, later the Kingdom of Yugoslavia, was established in 1920, the first legal texts which regulated this area had been enacted in 1884, when the Law on trademarks and the Law on design were adopted. Today, the Intellectual Property Office of the Republic of Serbia (IPO) that has changed its name and competences during more than 90 years of its existence, is an independent governmental institution in charge of all industrial property rights except plant varieties (which right is under the competence of the Ministry of Agriculture, Forestry and Water Management), as well as of copyright and related rights. Apart from administrative tasks, the IPO is also responsible for the following: application of international agreements regarding intellectual property protection, presentation and representation of interests of the Republic of Serbia in international organizations specialized in intellectual property protection, supervision of collective societies in the area of copyright and related rights, development of intellectual property protection, information and educational activities related to intellectual property protection.

Regarding the IPR legislation in the Republic of Serbia, the national IPR laws have been continuously harmonized with the EU legislation. This process has been intensified since 2000, when the Stabilisation and Association Process has been launched. Also, all international conventions administered by the World Intellectual Property Organization (WIPO) were ratified and implemented. After seven years of validity of the Agreement between the Federal Government of the Federal Republic of Yugoslavia and the European Patent 
Organisation on Cooperation in the field of Patents - Co-operation and Extension Agreement, in 2010, the Republic of Serbia became a member of the European Patent Convention, and thus a full member of the European Patent Organization (EPO).

Taking into consideration national and international regulations in force in the Republic of Serbia, the conclusion is that the Republic of Serbia provides a high quality legal ground for the protection of intellectual property, which complies with high international standards. However, there is a need for further work, particularly in the context of accession of the Republic of Serbia to the World Trade Organization and the further course of European integrations. This particularly relates to the EU accession process, since according to the Stabilization and Association Agreement (article 75 and 139) and the Interim Agreement (article 40, paragraph 3), the Republic of Serbia has an obligation to secure the level of protection of the intellectual property similar to the level existing in the Community, including efficient means for the enforcement of those rights, in the period of 5 years since the Interim Agreement entry into force.

In the last few years, the IPO has been in the process of intensive human resources transformation and modernization with the aim of increasing institutional capacities for the purpose of an efficient execution of its competencies. Largely due to the foreign aid (the EU funds, funds of the European Patent Office and the World Intellectual Property Organization), a considerable improvement has been achieved in the field of ICT infrastructure, which has also enabled the IPO stakeholders to use the web site of the IPO and access the national databases of the industrial property. This process continues in the context of extension and a general shift in focus of the IPO from the administrative tasks (conducting administrative procedure) towards client-oriented activities, such as providing information, education, mediation and coordination between the representatives of certain stakeholder groups.

Since 2008, the IPO has put a lot of effort in developing educational and information activities and providing support to the innovative stakeholders. The realization of these activities has been backed up by the EUfunded project "Support to the Establishment of the Education and Information Centre (EIC) in the IPO". Since January 2010, with the overall aim of streamlining IPO in this field, the EIC has been set and became fully operational. The main goals of the EIC are oriented towards: providing information on nationally granted rights by promoting the use of national databases, raising awareness and understating the benefits of IP, especially to the SMEs, and improving cooperation with all stakeholders' groups.

In July 2011, the Parliament of Serbia adopted the Strategy for the development of IP for 2011-2015 with a list of concrete measures to be implemented in order to advance the innovation in Serbia, stimulate direct foreign investment, influence the development of national knowledge based economy and stimulate research and development within Serbia. The Strategy's long term goal is to transform the Serbian economy from a predominantly net-user to a net-creator of IP. The Strategy focuses on four main areas: legal and institutional basis for the protection of intellectual property, suppression and sanctioning infringements of intellectual property rights, economic implementation of intellectual property and raising public awareness and education. The section of the Action Plan to the Strategy related to raising awareness and education included the increase in publicity and IP promotion, systematic planning awareness raising activities, provision of support for lecturing on IP at faculties and strengthening of the network between the EIC and business support institutions, universities, enforcement authorities and other IP stakeholders.

\section{Strengthening the client-oriented approach in the IPO of the Republic of Serbia}

Numerous results have been achieved in the last four years. Regarding dissemination of information and education among SMEs, the EIC and the IPO have developed specialized services for SMEs, such as the Intellectual Property Pre-diagnosis (IPP), the IP Response, tailor-made seminars for companies and specialized seminars and workshops in business support institutions (Serbian Chamber of commerce, network of chambers of commerce, National agency for regional development and network of regional development agencies) designed for their staff as well as for representatives of SMEs in their respective regions, and other.

\subsection{Intellectual Property Pre-diagnosis}

The IPP represents an evaluation of the intellectual property factors of any enterprise by the placement of IP into the appropriate context and taking into account numerous parameters. It has been designed for all enterprises wishing to assess their potency in the area of IP and to use it for their development. The IPP 
analysis provides guidelines to the enterprise for developing an IP strategy and including it in the corporate strategy management. Enterprises can benefit from this service in various ways. Primarily, IPP provides sincere diagnosis of the existing situation in the company in view of its needs in connection with industrial property, based on an objective and qualified analysis. Apart from examining the existing IP, this service offers clients a possibility to get an insight into potential future benefits that industrial property can generate. In that context, by simultaneously emphasizing the dimension of protection and the other aspects of exploiting industrial property, enterprises are offered support in deciding how and where to use their intellectual property. It is important to note that IPP focuses not only on patents, trademarks and other "standard" IP rights. It also includes identification of "soft IP" elements, such as know-how, confidential information and trade secrets. In light of that, companies also receive recommendations and suggestions for the management of these rights. Intellectual Property Pre-diagnosis is performed by experts of the Education and Information Centre of the Intellectual Property Office. The process consists of four steps: preparation for the visit to the enterprise, visit to the enterprise, compiling a report and delivering the report on IPP. Since the initiation of the service in July 2010 up to the end of 2013, 112 IPP visits have been carried out throughout Serbia. This resulted in new patent and trademark applications from the companies in which IPP has been carried out. In total, 69 applications for registering different intellectual property rights have been filed solely as a result of the IPP consultancy service (this number includes 3 patent applications, 2 petty-patent applications, 54 trademark applications and 10 industrial design applications).

\subsection{IP Response}

In September 2013, the IPO has launched the adjusted version of the IP Response in the Serbian language, which represents the tool originally developed by the Danish Patent and Trademark Office. This online tool provides an analysis of the knowledge potential and its alignment with companies' business. The service includes a 15-minutes test which a user completes online, with questions covering areas of business knowledge strategy, company procedures, resources and concrete business results. By collecting the necessary data from the user during test, the tool generates a report, which contains the main steps for managing intellectual property rights and other knowledge-related resources. In total, 35 companies have used this service from September to December 2013.

\subsection{Tailor-made seminars}

Since the establishment of the Education and Information Centre, this IPO department organized 339 educational events (seminars, workshops, conferences and other) for 8878 attendees. In relation to the seminars for SMEs, in the period from June 2010 to December 2013, the total of 86 educational events for 1791 participants were organized by the EIC alone or in cooperation with the business support institutions. However, the number of participants from SMEs in the educational events of EIC is higher, since many participants from the SME sector participated in other educational events which were organized not strictly for companies. Educational events normally include lectures on different intellectual property rights, application filing procedures and rules, IP management aspects, soft IP features and other, depending on the audience.

\subsection{Publications}

Regarding raising awareness and understanding benefits of IP among SMEs, the EIC and the IPO have published 18 different publications on intellectual property, which include guides, studies and handbooks. One of the most important publications is the study named "Small and Medium Enterprises and Intellectual Property" dated late 2010, which revealed an increase in influence of the IP protection on business in Serbia. In addition, the Education and Information Centre publishes the EIC Newsletter on a quarterly basis. The newsletter includes sections dedicated to stakeholders, education and information providing. It is published on the EIC website and also distributed in electronic and printed forms to stakeholders. A total of sixteen newsletters have been published so far. Publications of the Education and Information Centre also include various leaflets on specific IP rights, innovativeness and other IP-related issues.

\subsection{Support to the technology transfer process}

In November 2010, the IPO and the University of Belgrade signed the contract on support to the IPO and on establishment of a technology transfer office (TTO) at the University of Belgrade. The establishment of the TTO was specified in the IPA national project "Support to the establishment of the Education and Information Centre". The contract stipulates that both parties should cooperate on promoting and commercial- 
izing intellectual property rights, as well as on enhancing understanding and application of IPRs in various activities of the university. The TTO received strong support by the IPO as expert partner in relations between the university and economy and in improving the use of research results published at the university. It should also be noted that in 2008 IPO has reached a cooperation agreement with the Technical Faculty of the University of Novi Sad. In relation to educational activities towards academia, the Education and Information Centre carried out 107 educational events (lectures, round tables and workshops) for faculties, institutes and secondary schools in the period from June 2010 to December 2013. The Intellectual Property Office also supports the TEMPUS project of setting up TTOs at universities of Novi Sad, Kragujevac and Niš.

\subsection{Other activities of the EIC in the period 2010-2013}

Other activities aimed at raising awareness on IP include 28 conferences for public, 26 appearances of the EIC experts at specialized fairs as organizing or lecturing party and 36 Open Door consultations, which include a 2-hour provision of information on all IP types in direct consultation with interested parties in the premises of the IPO one day per month. In order to support capacity building in the field of IPR enforcement, the IPO and the EIC have organized comprehensive training for enforcement authorities in Serbia in 2011 and 2012. The training was carried out for various groups of stakeholders: Market inspectorate, Customs administration, Police and representatives of courts and public prosecution offices, Tourism inspection and other. It was divided into basic and advanced training and comprised 39 seminars in total. For this purpose, experts from the United Kingdom and Denmark were engaged as lecturers together with experts from the IPO of Serbia.

\section{Recent trends in IPR applications}

Like most of the national IP offices in the world, the IPO of Serbia does not keep any record on the exploitation of intellectual property rights by their respective holders, making it very difficult to assess the actual efficiency of the use of particular intellectual property rights on the market. Therefore, filed applications for particular IP rights are generally used as indicators of the use of IP system by companies and other IP stakeholders. Looking at the ten-year statistical data of filing domestic patent applications, it is evident that the share of patent applications from companies and faculties and institutes has been slightly growing in recent years. It should be noted that the number of patent applications from these entities experienced steep growth in 2012. Regarding the applications from companies, this strong upward trend continued in 2013, while the number of patent applications from universities and institutes declined to the level recorded in 2011. As far as trademark and design applications are concerned, they experienced a slight decline in 2012 , followed by the sharp increase of the number of applications in 2013. The upward trends are considered to be largely linked with the increase in EIC educational and awareness raising activities and the introduction of IP-specialized services in the last three years.

The following table contains the data on patent, trademark and industrial design applications filed in the period between 2011 and 2013. The data from this period have been selected and presented based on the fact that the full availability of the new IPO services and the increase in the number of seminars and workshops were achieved only from the second half of 2010.

Table 1: Domestic patent, trademark and design applications for years 2011-2013:

\begin{tabular}{|l|c|c|c|}
\hline \multicolumn{1}{|c|}{ IPR applications / Year } & $\mathbf{2 0 1 1}$ & $\mathbf{2 0 1 2}$ & $\mathbf{2 0 1 3}$ \\
\hline Patents applications from companies & 8 & 18 & 31 \\
\hline Patents applications from universities and institutes & 21 & 30 & 19 \\
\hline Trademark applications & 1135 & 1113 & 1334 \\
\hline Industrial design applications & 78 & 66 & 94 \\
\hline
\end{tabular}


Economic growth relies on knowledge. However, there is a need to put knowledge in a framework which enables its management, in terms of materialization, protection and commercialization. The system of intellectual property rights supports this process. If there were no clearly defined intellectual property rights, the market would not allow individuals and firms to exclude potential competitors from using new knowledge, therefore undermining exploitation efforts, benefits and also future investments into research and new knowledge generation. A general attitude is that the intellectual property system in the Republic of Serbia provides a fertile ground for the enhancement of creativity and innovativeness. For several years now, the Intellectual Property Office of the Republic of Serbia provides services of IPR registration and also educational activities for various groups of stakeholders. In addition to this, the activities of the Education and Information Centre, which was established in 2010, strongly increased the raising of awareness and educational activities of the Intellectual Property Office. In the last few years, an increase in domestic patent applications filed by companies has been recorded. The upward trend has also been shown at trademark and design applications, which can be generally attributed to companies as filing parties. The recorded trends send a signal that the awareness of the benefits of the IP system among companies in Serbia has been increased. The upward trends coincide with the strengthening of the awareness raising and specialized IP consultancy efforts by the Intellectual Property Office. This particularly refers to a large number of participants at seminars organized by the Education and Information Centre and also to the results of the IPP consultancy service performed for companies in Serbia. We can, therefore, conclude that newly developed specialized services and the increase in awareness raising activities of the Intellectual Property Office, particularly with the support of its department the Education and Information Centre, greatly contribute to the increase in use of the IP system by companies in Serbia.

\section{REFERENCES:}

[1] Al-Ali, N. (2003). Comprehensive Intellectual Capital Management. John Wiley \& Sons, New Jersey.

[2] Bader, M. (2006). Intellectual Property Management in R\&D Collaborations. The Case of the Service Industry Sector. Physica-Verlag, Heidelberg.

[3] B. Bilen-Katić. (2010). Uspostavljanje kancelarija za transfer tehnologija na Univerzitetu u Beogradu. Tematski zbornik radova XVII naučnog skupa međunarodnog značaja "Tehnologija, kultura i razvoj", Sept. 1-2, 2010, Tivat, Montenegro, pp. 223-232. Akademska misao: Belgrade.

[4] Brkanović, I. (2010). Small and Medium Enterprises and Intellectual Property. Center for Development of Entrepreneurial Society. Intellectual Property Office. Retrieved from http://www.zis.gov.rs/upload/documents/pdf_en/pdf/Study_SMEs_and_Intelectual_PropertyEN_final.pdf

[5] Cowan R. \& Harison, E. (2001). Intellectual Property Rights in a Knowledge-Based Economy. Paper drawn from the report commissioned by AWT published as AWT Background Study No. 21 (June 2001). MERIT, University of Maastricht.

[6] Government of the Republic of Serbia. (2011). Strategy of the Intellectual Property Development. Official Gazzette of the Republic of Serbia, No. 49.

[7] Grandstand, O. (1999). The Economics and Management of Intellectual Property. Edward Elgar. Northampton, MA.

[8] Harris, M., Harris, P. \& Hannah, S. (1998). Into the Future: The Foundations of Library and Information Services in the Post-Industrial Era. Ablex Publishing Corporation, Greenwich, CT.

[9] Intellectual Property Office of the Republic of Serbia. (2013). Annual Report for 2012. Retrieved from http://www.zis.gov.rs/upload/documents/pdf_sr/pdf_o_nama/Gl2012\%20final_web.pdf

[10] Intellectual Property Office of the Republic of Serbia. (2012). Annual Report for 2011. Retrieved from http://www.zis.gov.rs/upload/documents/pdf_sr/pdf_o_nama/Gl2011_web.pdf

[11] Intellectual Property Office of the Republic of Serbia. (2011). Annual Report for 2010. Retrieved from http://www.zis.gov.rs/upload/documents/pdf_sr/pdf_o_nama/Godisnji\%20izvestaj\%202010\%20web.p df

[12] Intellectual Property Office of the Republic of Serbia. (2013). Informator o radu. [Document in Serbian] Retrieved from http://www.zis.gov.rs/upload/documents/pdf_sr/pdf/Informator/2013/Informator_decem bar\%202013_ver\%2001.pdf

[13] Kanwar S. \& Evenson, R. (2009). On the strength of intellectual property protection that nations provide. Journal of Development Economics 90, 50-56. 
[14] Levi-Jakšić, M. ed. (1995). Inovativno preduzeće, Fakultet organizacionih nauka, Beograd.

[15] Sveiby, K.E. (1997). The New Organizational Wealth: Managing and Measuring Knowledge-Based Assets. Berrett-Koehler, San Francisco.

[16] Caenegem, W. V. (2002). Intellectual Property and Intellectual Capital. Bond University, Faculty of Law, Law papers.

[17] Yang, L. \& Maskus, K.E. (2009). Intellectual property rights, technology transfer and exports in developing countries. Journal of Development Economics 90, 231-236.

Receieved: November 2013.

Accepted: March 2014
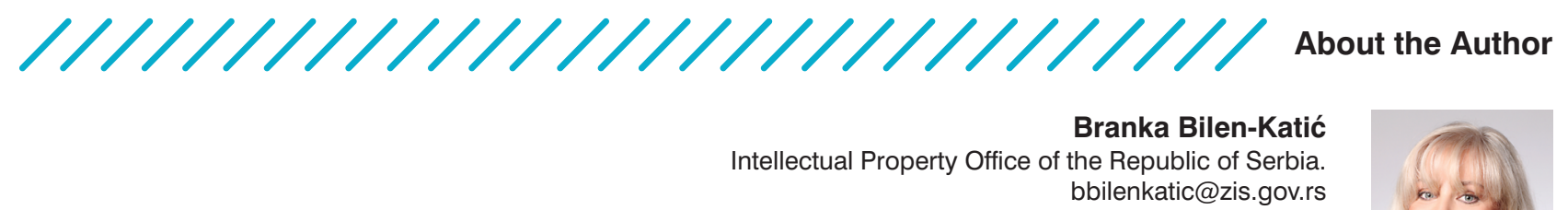

Branka Bilen-Katić is an assistant director at the Intellectual Property Office of the Republic of Serbia and holds an M.Sc in mechanical engineering and naval architecture. Her areas of expertise include public administration and European integrations. She is specialized in intellectual property and project management issues. She is also author of many articles published in specialized technical journals.

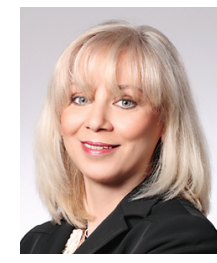

Nikola Radovanović Intellectual Property Office of the Republic of Serbia nradovanovic@zis.gov.rs

Nikola Radovanović is a consultant and lecturer at the Intellectual Property Office of the Republic of Serbia and a Ph.D. candidate at the University of Belgrade, with the background in economics. He is specialized in knowledge management and intellectual property management. Nikola Radovanović published several papers and articles on the topics of knowledge management and intellectual property in specialized journals

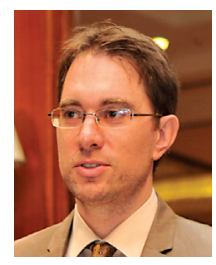
and magazines in Serbia and abroad. 